\title{
REVIEW OF HISTORICAL SEISMICITY OF WEST-CENTRAL BRAZIL: NEWLY DISCOVERED EVENTS AND IMPLICATIONS FOR SEISMIC HAZARD
}

\author{
Lucimara José da Silva1', Marcelo Assumpção² and Edna Maria Facincani ${ }^{3}$
}

\begin{abstract}
The Pantanal basin seismic zone has experienced earthquakes with magnitudes up to $5.4 \mathrm{mb}$. New information on historical events was searched for in regional newspapers, especially the "Correio do Estado", Campo Grande, Mato Grosso do Sul State, Brazil. Several small new events, not previously reported in the Catalog of Berrocal et al. (1984), were discovered. Five events had new macroseismic information from different localities allowing magnitudes to be estimated from the felt area. Ten new events were also discovered, each one felt in a single locality. The event of 1906-Oct-24, with previous magnitude 4.2, was felt in a larger area indicating magnitude $4.9 \mathrm{mb}$. The large event of 1919-June-01, reported in the Catalog with $4.9 \mathrm{mb}$, was false, and had resulted from joining a local tremor probably due to a meteorite fall in Santa Luzia (GO) with wrong interpretation of records of the RDJ station, Rio de Janeiro, as if they were from the same event in Mato Grosso. The revised catalog for the West-Central Brazil, compared with geophysical maps, shows that earthquakes occur in areas of low velocities in the upper mantle, as well as in areas of positive gravity free-air anomalies. Stress concentration in the upper crust can be explained as due to both lithospheric thinning and flexure.
\end{abstract}

Keywords: historical seismicity, Pantanal, macroseismic information.

RESUMO. A zona sísmica da bacia do Pantanal tem sismos até $5,4 \mathrm{mb}$. Informações mais detalhadas sobre eventos históricos foram pesquisadas em jornais regionais, especialmente o "Correio do Estado", Campo Grande, Mato Grosso do Sul. Vários pequenos eventos novos foram descobertos que não constavam do Catálogo anterior de Berrocal et al. (1984). Cinco eventos tiveram novas informações macrossísmicas de diferentes localidades, permitindo estimar magnitudes pela área afetada. Foram descobertos dez novos eventos, cada um com informações de uma única localidade. O evento de 24-Out-1906, com magnitude anterior 4,2, foi sentido em uma área maior, indicando magnitude de 4,9 mb. Já o grande evento de 01-Jun-1919, relatado no Catálogo com magnitude $4,9 \mathrm{mb}$, era falso, sendo resultado da junção de um tremor local, possivelmente devido à queda de um meteorito em Santa Luzia (GO), com interpretação errada dos registros da estação RDJ (Rio de Janeiro), como se fossem provenientes de um único evento em Mato Grosso. O catálogo revisado para a região Centro-Oeste do Brasil, comparado com mapas geofísicos, mostra que os sismos ocorrem em áreas de baixas velocidades no manto superior, bem como em áreas de anomalias ar-livre positivas. A concentração de tensões na crosta superior pode ser explicada tanto por afinamento litosférico, como por flexura.

Palavras-chave: sismicidade histórica, Pantanal, informação macrossísmica. 


\section{INTRODUCTION}

West-Central Brazil, especially the Pantanal basin, is known as a seismic area since the early studies of Branner (1912). The causes of seismicity in stable continental region are still a matter of debate, but there is a general consensus that stress concentration in the upper crust is one of the main contributing factors (e.g., Mazzotti, 2007; Talwani, 2014). Studies of Brazilian seismotectonics (e.g., Assumpção \& Sacek, 2013; Assumpção et al., 2004, 2014), show that two factors could produce stress concentrations in the upper crust in areas like the Pantanal: thin lithosphere in areas of low seismic velocities in the upper mantle, and flexural deformation from lithospheric loads due to a thin crust. The possible continuation of the Transbrasiliano Lineament (TBL) beneath the Pantanal basin has also been cited as a possible evidence of crustal weakness. However, the recently adopted trace of the TBL (Cordani et al., 2016) goes south of the Pantanal (Fig.1).

The Brazilian seismic catalog, as used by USP and UnB (Fig. 1), is the result of the main compilation of Berrocal et al. (1984), hereafter referred to as the "Catalog", with events up to 1983. Later events were added by various annual bulletins published from 1984 to 1995 in Revista Brasileira de Geofísica (Brazilian Geophysical Journal), and by joint work of Brazilian universities and research institutes (USP, UnB, UFRN, IPT and ON) since then. Here, we contribute to complement the historical data, for West-Central Brazil (Mato Grosso do Sul - MS, Mato Grosso - MT and Goiás - GO states) up to 1981.
Data from historical events were searched for using two main sources of on-line digitized newspapers: 1) the National Library, Rio de Janeiro (https://www.bn.gov.br), and 2) the "Correio do Estado", Campo Grande, MS. For the National Library, an extremely useful search tool using keywords is available. For the "Correio do Estado", all issues were read manually by Silva (2017) in search for news on local earthquakes. Information on 27 earthquakes were found, 13 of which were new events not mentioned in the Catalog of Berrocal et al. (1984). Additional information on 11 events were related to non-seismic events, such as meteorite fall. Details of all information recovered in these searches can be found in Silva (2017). Here we only report the macroseismic information about the main events.

\section{RESULTS OF THE HISTORICAL SEARCH}

Table 1 lists all events for which new information were found. The new events, not previously listed in the Catalog, are identified by "ns" in column 2; those which were already in the Catalog, but for which new contributing information was found, are identified as "c" in column 2.

For the events with felt reports in different localities allowing a rough estimate of the felt area, a magnitude was assigned based on felt area with the empirical equations:

total felt area, $A f$ (Assumpção et al., 2014)

$$
\begin{aligned}
m b=2.44 & -0.015 \log (A f) \\
& +0.092[\log (A f)]^{\wedge} 2
\end{aligned}
$$




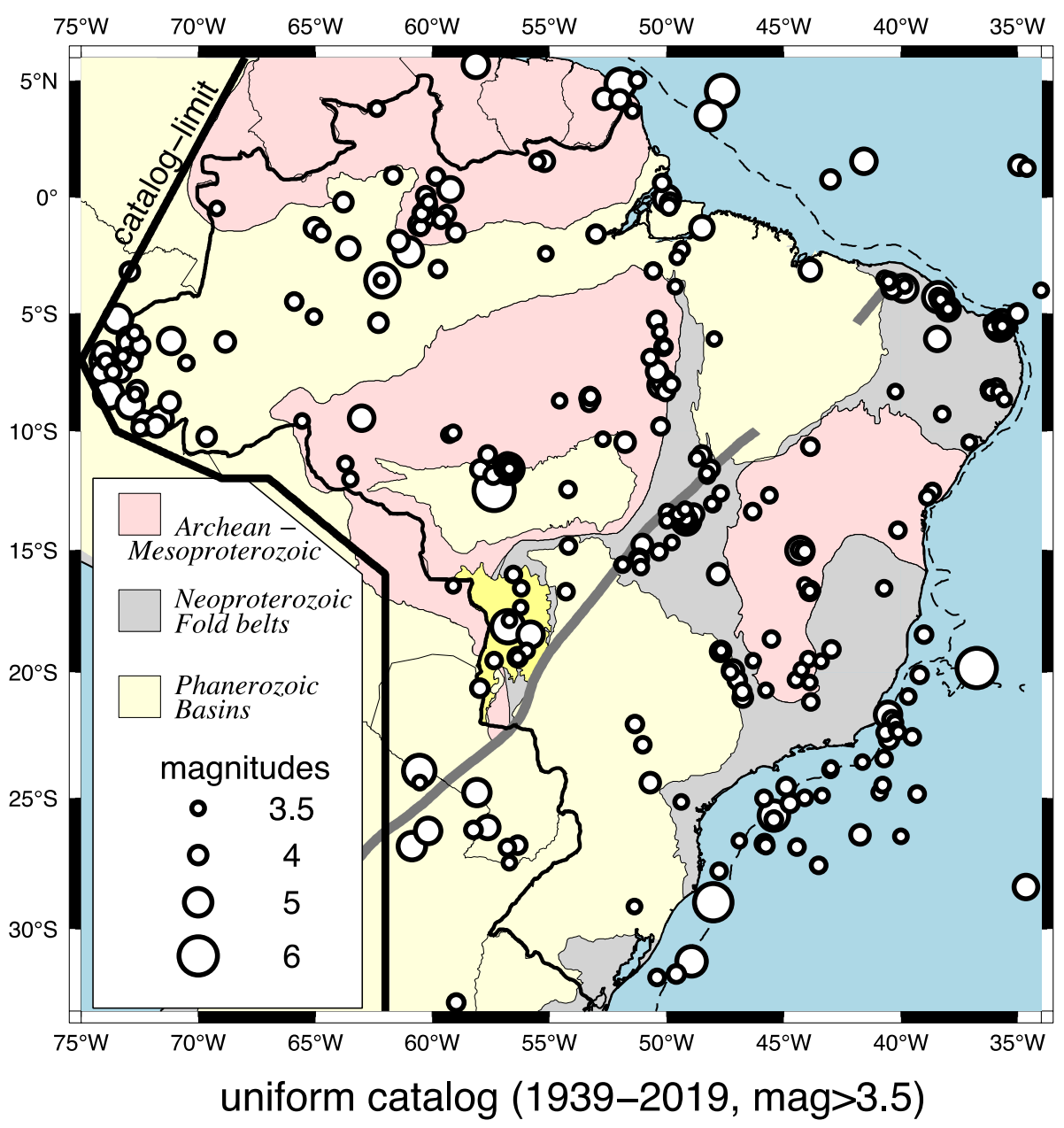

Figure 1 - Brazil seismicity and the main geological provinces. Circles are epicenters filtered for "uniform" coverage, as in Bianchi et al.(2018). The dark yellow area is the Pantanal basin, and the gray line is the Transbrasiliano Lineament (Cordani et al., 2016)

felt area $A_{I V}$ (Berrocal et al., 1984)

$$
m b=2.29+0.55 \log \left(A_{I V}\right)
$$

For events with macroseismic information from a single location, allowing an estimate of the maximum epicentral intensity (lo), we adopt the same criteria of Assumpção \& Burton (1985) and assume it was a local, shallow event whose magnitude can be estimated by:

Io

$$
m b=1.21+0.45 I o
$$

Here we also use the Brazilian regional magnitude, mR (Assumpção, 1983) as equivalent to the teleseismic mb magnitude. We now briefly describe the most relevant information on the seismic events found in this search.

\section{August 13 - 17h - Cuiabá, MT}

This event was in the Catalog, but dated as 1860October-01. The newspaper "A Imprensa" (Cuiabá, 1860-Sept-09, Ed. n. 60, pages 1 and 3) states 
clearly that the event occurred on August 13th. This was reproduced by "Jornal do Commercio", Rio de Janeiro, 1860-Nov-08. This means the date used in the Catalog was not the correct one. New information was found: the event was reported to have "caused small damage in Caridade street and towards Bahú" ("ocasionou alguns estragos na rua da Caridade e para o lado do Bahú"). It was also felt in Pari (presently part of Cuiabá) and Livramento ("6 leagues from the Capital", that is 42 $\mathrm{km}$ ), and may have been felt up to 10 "leagues" away ( 60 km) ["A Imprensa de Cuyabá" 1860Sept-09; 1860-Aug-19 reproduced by "Jornal do Commercio", Rio de Janeiro, 08-Nov-1860-Nov08]. Assuming an epicenter half-way between Cuiabá and Livramento $\left(15.7^{\circ} \mathrm{S}, 56.2^{\circ} \mathrm{W}\right)$, the approximate size of the felt radius ( $\sim 50 \mathrm{~km})$, or $\sim 25$ $\mathrm{km}$ for intensity IV MM in Cuiabá, suggests a magnitude of about $3.8(A f)$ or $4.1\left(A_{I V}\right)$. We adopt a magnitude 4.0 for this event.

\section{June 04 - 17h - Goiás Velho, GO}

"O Paiz", São Luiz, MA, 1887-July-02, cites a newspaper from the Goiás capital reporting a possible tremor "ouvido estampido longo e surdo, que durou perto de dez minutos. Julgase que talvez tenha sido algum tremor de terra" ["a long, deafening sound was heard, which lasted close to ten minutes. It is thought that perhaps it was an earthquake"]. The old capital of Goiás state is presently named Goiás Velho. The "10 min duration" is almost certainly not correct, but is a common description of old historical events by untrained people. It is not used to assess intensity or magnitude of the event.

\section{November 09 - Jaraguá, GO}

Strong "explosions" were felt in Jaraguá, GO, interpreted as an earthquake. The same was felt in Pirenópolis and Corumbá de Goiás: "A 9 de novembro ouviram-se fortes detonações nas proximidades de Jaraguá as quaes presume-se serem indicios precursores de algum terremoto. As detonações foram ouvidas com a mesma intensidade em Pyrenopolis e Corumbá" ["On 9 November, heavy detonations were heard in the vicinity of Jaraguá, which are presumed to be precursor signs of an earthquake. The detonations were heard with the same intensity in Pyrenopolis and Corumbá']. ["Estado de Goyás" 1894-Nov-28]. An epicenter about half-way between Jaraguá and Pirenópolis would imply a felt radius of about 45 $\mathrm{km}$, giving an estimated magnitude of about 3.7. No actual shaking of the ground was described, and so there is a possibility that this was not a real earthquake but just effects of a meteorite, or a bolide perhaps. However, more emphasis on sounds rather than tremors are not uncommon in felt reports.

\section{October 24 - 22:58 - Corumbá, MS}

The Catalog (Berrocal et al., 1984) reports an event felt in Corumbá, Coimbra and Miranda, including information from the Seismic Bulletin of the National Observatory. New information shows it was also felt in Nioaque, and not felt in Aquidauana and Cuiabá (Fig. 2). A telegram from Corumbá reports a "strong shock" ("forte tremor") at 10:58 PM ("11 horas menos dois minutos") lasting $10 \mathrm{~s}$ [Correio da Manhã, Rio de Janeiro, 1906-Oct-26; the telegram was sent from Corumbá in the morning of the 25th]. 


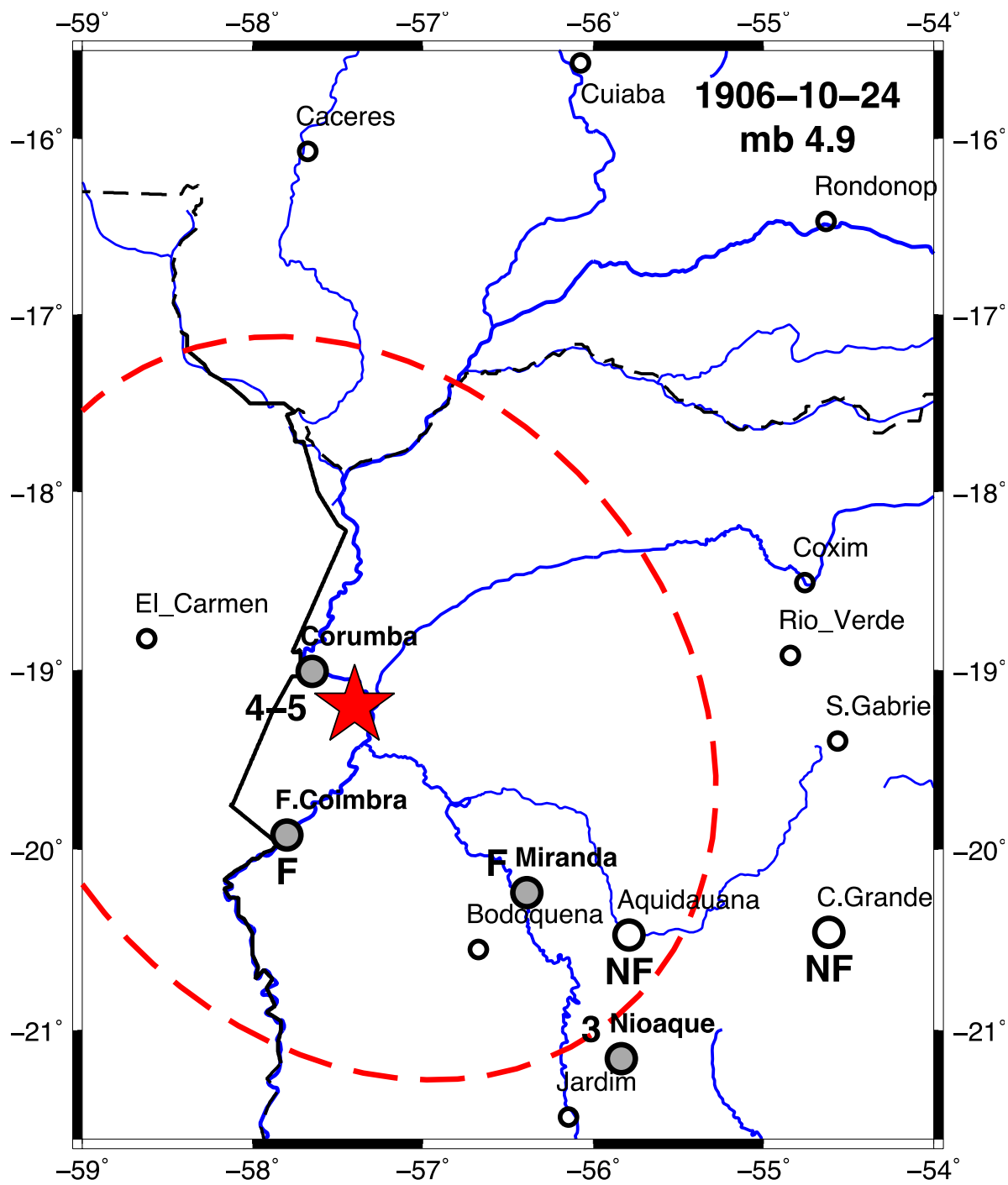

Figure 2 - 1906-Oct-24 macroseismic map. Large circles are localities for which intensity information was found; small circles are other localities for which no information at all was found. Numbers 3 and 4-5 are Modified Mercalli intensities; F is "Felt"; NF is "Not Felt". Red star is the proposed revised epicenter. The larger dashed line ellipse is an estimate of the felt area, used to assign a magnitude $\mathrm{mb} 4.9$.

The newspaper "O Pharol", Cuiabá, 1906-Oct-27, reports that in Nioaque slight tremors were felt lasting 5 minutes ("sentiram-se em Nioac brandos tremores de terra com duração de 5 minutos" ["In Nioaque slight tremors were felt with $5 \mathrm{~min}$ duration"]), and that in Corumbá a weak tremor lasting $4 \mathrm{~s}$ caused light damage and alarmed the population ("pequeno tremor de terra que durou quatro segundos causando estragos de pouca importância. População sobressaltada."). The "Jornal Official", Victoria, ES, 04-Nov-1906, reports that in Corumbá "Sentiu-se, à 11 horas da noite, tremor de terra, que durou mais de 15 segundos. Começou fraco, teve um momento de parada e 
terminou forte. Não houve desastre a lamentar. Em Coimbra sentiu-se também um abalo às 10 horas e 25 minutos. Em Aquidauana e Cuyabá nada se sentiu" ["At 11 pm, an earthquake was felt, which lasted more than 15 seconds. It started out weak, had a moment of pause and ended up strong. There was no disaster to lament. In Coimbra a shock was also felt at 10 hours and 25 minutes. In Aquidauana and Cuiabá nothing was felt" ]. Branner (1912) says the event was felt in Miranda, based on news from Jornal do Commercio, Rio de Janeiro, 1909-Jan-23(?). He estimates an intensity of IV-V in the Rossi-Forel scale (also corresponding to IV-V MM, compatible with possibly very slight damage and people getting frightened).

A telegram received from Cuiabá on the 26th by the newspaper "Gutenberg", Maceió, AL, 1906-Oct-27, says that "Aqui, em a noite de hontem, cerca de $11 \mid 2$ hora depois meia noite, foi sentido forte tremor de terra. O estremecimento durou 10 segundos. A população assombrada tomou-se verdadeiro panico. Muitas pessoas abandonaram as habitações demandando os campos. Ha grande apprehensões motivada por esse phenomeno sismico" ["Here, yesterday night, about 1 1|2 hours after midnight, a strong earthquake was felt. The vibrations lasted for 10 seconds. The scared population was in real panic. Many people left the houses seeking the fields. People are worried because of this seismic phenomenon"]. The reported time does not seem compatible with the event felt in Corumbá. Besides, the newspaper "O Pharol", Cuiabá, give news of Corumbá and Nioaque but does not mention anything about Cuiabá. So, it is not possible yet to include Cuiabá in the felt area.
The "Diário de Natal", Natal, RN, 1906-Nov01, received a telegram from Bolivia reporting a strong earthquake in Cochabamba and mentions the possibility that it could be the same event felt in Cuiabá. In the CERESIS catalog, there are no major earthquakes in Bolivia in 1906. The Bolivian newspaper "Diario de La Paz", 1906-Oct-25, clearly reports that the Cochabamba event occurred in October 23, at "3 y 27 p.m." (that is $15: 27$ local time), and so is clearly a different event.

The felt area shown in Figure 2, assuming a long ellipse with $245 \mathrm{~km}$ major axis, has an area of $100.000 \mathrm{~km}^{2}$, indicating a magnitude of about 4.7. If the felt area is taken as a circle of $245 \mathrm{~km}$ radius $\left(190.000 \mathrm{~km}^{2}\right)$, the magnitude would be $4.9 \mathrm{mb}$.

The Seismic Bulletin of the National Observatory (Lemos, 1921) shows an arrival recorded at the seismic station RDJ on October 25, at 02:49:30 (UTC) interpreted as a $\mathrm{P}$ arrival (read in the EW component). Beside this reading there is a note saying: "25-10: Fraco movimento sismico sentido em Corumbá às $10^{h} 52^{m}$, hora local. Sentido igualmente em Coimbra, porém, não em Cuyabá." ["10-25: Weak seismic movement felt in Corumbá at $10 \mathrm{~h} \mathrm{52m,} \mathrm{local} \mathrm{time.} \mathrm{Felt}$ equally in Coimbra, however, not in Cuyabá"] It is not entirely clear if the Corumbá earthquake was really recorded at RDJ. The distance (1500 to $1600 \mathrm{~km}$ ) seems too large for a magnitude $<5$ to be recorded at the old instruments operated at the time. There is a possibility that the RDJ records correspond to some Andean earthquake. Or, the Corumbá earthquake should have a much larger magnitude and felt area. 
1910 December - Crixás, GO

"...em Dezembro do anno findo,... em Crixás houve forte tremor de terra naquelle mez, e que o povo ficou amedrontado mas, não houve prejuízos nem victimas a lamentar" ["...In December last year,... in Crixás there was a strong earthquake in that month, and the people got scared but there was no damage nor victoms"] (O Planalto, Santa Luzia, GO, 1911-Apr-22].

\section{July 30 - 20hs - Coxim, MS}

"Na noite de 30 do mez passado deu-se no Coxim, às 8horas da noite, um leve tremor de terra que durou dez segundos, durante o qual notou toda a população daquella Villa um rumor fortíssimo no sub-solo" ["On the night of the 30th of last month, there was a slight earthquake in Coxim, at 8pm, which lasted ten seconds, during which the entire population of that Villa noticed a very strong rumor in the sub-soil"] (O Commercio, Cuiabá, 1911-Aug-01). The newspaper "A Noite", Rio de Janeiro, 1911-July31 , also reports news received by the National Observatory: "O phenomeno sismico operou-se ontem ás 8 horas da noite, sendo sentido no sub-solo em Coxim por todos os habitantes. $O$ primeiro tremor ... foi seguido de pequenos abalos sismicos, mais sentidos na direcção do occidente. ... Confirmando essa primeira observação, o Observatório recebeu á tarde o seguinte telegramma: 'Coxim, (8 horas) Hontem ás 8 horas p.m foi ouvido nesta localidade por todos habitantes um rumor no sub solo acompanhado pequeno tremor de terra na direcção poente' " ["The seismic phenomenon took place yesterday at $8 \mathrm{pm}$, being felt in the subsoil in Coxim by all the inhabitants. The first tremor ... was followed by small seismic shocks, felt more towards the west. ... Confirming this first observation, the Observatory received the following telegram in the afternoon: 'Coxim, (8 am) - Yesterday at 8 pm a rumor in the sub-soil was heard in this locality by all inhabitants, accompanied by a small earthquake in the west direction. ' "]. The reports of "slight tremor" being felt by "all the population" are somewhat inconsistent, but an estimated intensity of IV can be assigned.

The newspapers also reported that the Wiechert seismographs of the National Observatory recorded several shocks during the night of July 30 . However, this initial interpretation of the RDJ records is most probably incorrect. The RDJ seismographs had a magnification of only 15 and usually only recorded long period waves of large teleseisms (magnitudes 7 or above). The final RDJ bulletin (Lemos, 1921) does not mention any record from a regional earthquake on July 30 .

\section{January 06 - Cuiabá, MT}

This event, already listed in the Catalog, is reported in the newspaper "A Razão", Rio de Janeiro, 1918-Jan-12, to have occurred on January 6th, based on a message received by the National Observatory from Monsenhor Coutrouron, a resident of Cuiabá saying: "foi violento e durou pouco mais de um minuto. Não temos a registrar desastres pessoal ou material por isso que elle se manifestou em zona despovoada" ["it was violent and lasted just over a minute. We do not record personal or material disasters that is why it manifested itself in a depopulated area"]. 
1919 March 12 - 08:45 - Porto Esperidião, MT

"Telegramas de Cuyabá dizem que no dia 12, 8.45 minutos, em Porto Esperidião ... houve um forte tremor de terra que durou um minuto. Houve alarma da população" ["Telegrams from Cuyabá say that on the 12th, 8.45 minutes, in Porto Esperidião ... there was a strong earthquake that lasted one minute. There was alarm in the population "] (O Combate, São Paulo, SP, 1919-Mar-19).

\section{June 01 - Corumbá, MS - Doubtful event}

The Catalog (Berrocal et al., 1984) lists two events on this date:

(1) one in Santa Luzia, Goiás, mentioned by Branner (1920): "a light earthquake was felt at 6:30 p.m. June 1, 1919, at Santa Luzia, State of Goyaz. It was strong enough to rattle glassware upon the shelves and to disturb the furniture somewhat. It lasted about four seconds, and was accompanied by a rumbling sound." No source is given for this information.

(2) another event in Mato Grosso, also mentioned by Branner (1920): "It has been reported to the National Observatory of Rio de Janeiro that an earthquake was felt at Corumbá and Cuyabá, State of Matto Grosso, in June 1919; it is said to have lasted eight minutes [sic]. The exact date is not given".

The Catalog has interpreted these two events as if they were a single earthquake felt in a large area with a magnitude of $4.9 \mathrm{mb}$. The RDJ bulletin (Lemos, 1921) shows an event with a $P$ arrival around 21:38:24 on June 1st. The information is confusing (it shows an $\mathrm{S}$ arrival at 21:00:54, before the $P$ ), and does not seem to be compatible with an earthquake in Mato Grosso or Goiás. The annotation in the Bulletin says this event was also recorded by the station in Georgetown, Guyana. La Paz station, Bolivia, also recorded some signal on June 1st, $21 \mathrm{hs}$. The only reference to a Brazilian epicenter in the RDJ Bulletin is the annotation "(?) Brasil" beside a record of July 10, 24:55:12 (phase "M") corresponding to an eP arrival at 24:51:48 ("24hs" was actually used in the RDJ bulletin) There is no evidence of an earthquake in Brazil at this time (Berrocal et al., 1984).

The newspaper "Correio da Manhã", Rio de Janeiro, 1919-Jun-03, transcribes the following telegram: "Santa Luzia, 2 - Hontem, ás 6 horas e meia, esta cidade foi fortemente abalada por um tremor de terra. A população daqui está sob verdadeiro alarma. - M. Henriques" ["Santa Luzia, 2 - Yesterday, at 6:30, this city was badly shaken by an earthquake. The population here is under real alarm. - M. Henriques"]. The newspaper "Voz de Luziania", Luziania, GO, 1983-Nov-06, mentions the book "Efemérides" by Gelmires Reis, a local historian and journalist of Goiás, which reports that he had heard a frightening sound and strong tremor on June 1st, 1919 , at $18 \mathrm{hs}$. Gelmires Reis started looking for the cause of that tremor and found, nine years later, on 1928-July-09, a meteorite which he called "Santa Luzia de Goiás". The newspaper "Correio de São Paulo", São Paulo, 1937-Mar23, describes the history of this meteorite which was found in "Fazenda Paiva", 18 km from Santa Luzia (presently Luziânia, GO; the farm is now called "Faz. Porta do Céu"). It seems the 
"strong tremor" in Santa Luzia could be due to the fall of a meteorite. Although the exact date of the meteorite fall is not known, the association with the "earthquake" of 1919-Oct-01 is a reasonable hypothesis. Santa Luzia is the 5th largest meteorite known in Brazil: its weight of 2 tons could have caused vibrations felt like an earthquake.

No news from any newspaper was found to confirm the information of Branner (1920) of a tremor felt in Corumbá and Cuiabá in June 1919. Several newspapers (such as "A Noite", Rio de Janeiro, 1919-July-11) report an interpretation of the National Observatory that a signal at RDJ seismographs at 21:51:40, on July 10, at an "epicentral distance of $1300 \mathrm{~km}$ and E-W direction made us predict that it was felt in the south of Matto Grosso" ["distancia epicentral de 1300 km e direcção E-W fez-nos prever ter sido o mesmo sentido na região sul de Matto Grosso."] It is not clear if the RDJ Bulletin (Lemos, 1921) really reports a Brazilian event. The kind of seismograph used at the time did not allow the determination of the direction of the waves. It seems that the information from Branner (1920) was a misinterpretation of the initial reports from the National Observatory.

If the same earthquake had been felt both in Corumbá and Luziânia, called Santa Luzia before 1943, with a magnitude around 5, it should have been widely felt in many other towns in the region, such as Coxim, MS, Goiás Velho, GO, and maybe Rondonópolis, MT. Our conclusion is that no event occurred in Mato Grosso in June 1st, 1919, and so this information should be removed from the Brazilian catalog.
1919 July 10 - 21:51 - Mato Grosso State?

The newspapers "A Noite", Rio de Janeiro, RJ, 1919-July-11, and "O Combate", São Paulo, SP, 1919-July-12, report a communication from the National Observatory about the recording of an earthquake possibly in Mato Grosso. Again, this is most probably a misinterpretation of the RDJ seismograms. There is no news of any event felt in Mato Grosso that evening. The RDJ bulletin reports an earthquake with P wave arriving at "24:51:39" (among other phases) and a small side note "(?) Brasil". This is probably the recording of a large earthquake elsewhere in the planet, not in Mato Grosso.

\section{April 01 - 03hs - Porto Murtinho, MS}

The newspaper "O Jornal", Rio de Janeiro, 1922-Apr-04, reports that in Porto Murtinho at "três horas da manhã...foi sentido nesta cidade um forte tremor de terra, precedido de um barulho como trovoada" ["three o'clock in the morning ... a strong earthquake was felt in this town, preceded by a noise like thunderstorm"]. The "Commercio do Paraná", Curitiba, 04-April-1922, also reported that "Em Porto Murtinho, Matto Grosso, foi sentido forte movimento sísmico, ouvindo-se um rugido. A inquietação é geral, temendo-se um tremor de terra." ["In Porto Murtinho, Matto Grosso, a strong seismic movement was felt, with a roar. The restlessness is general, fearing an earthquake."] 
1922 April 30 - Lages(?), MT?

"O Jornal", São Luis, MA, 1922-May-03, says

"Rio, 1 - O Jornal - Em Lages, Mato Grosso, hontem houve forte tremor de terra" ["Rio, 1 O Jornal - In Lages, Mato Grosso, yesterday there was a strong earthquake"]. We could not find Lages in Mato Grosso.

\section{November 07? - Anápolis, GO}

"A Noite", Rio de Janeiro, 1925-Nov-09, gives information, dated November 7th, that an earth tremor was felt in Anápolis.

\section{May 08 - 21hs - Coxim, MS}

"A Noite", Rio de Janeiro, 1931-May-11 and 1931-Jun-02, transcribe a telegram from Aquidauana reporting "a violent earth tremor" in Coxim "damaging many buildings", "no victims". The damage is probably exaggerated, taken into account that no more news of this event was ever published. An intensity $V M M$ is tentatively assigned.

\section{August 23? - Damianópolis, GO}

A few earth tremors were felt in Damianópolis followed by strong roaring. People ran to the church (Diário da Noite, Rio de Janeiro, 1944Aug-23). Another light tremor was reported in October (Diário da Noite, Rio de Janeiro, 1944Oct-12) described as "ligeiro tremor de terra; sentido de forma nítida tendo as casas estremicido" ["slight earthquake; felt clearly having the houses shaken"]. An intensity IV is tentatively assigned for this series.

\section{January 18 - 16:15 - Cuiabá, MT}

The Catalog lists this event felt in Cuiabá without any detail. The "Correio do Estado", Campo Grande, 1957-Jan-19, and "O Estado de Mato Grosso", Cuiabá 1957-Jan-20, report that an event occurred in Cuiabá and was recorded precisely at $16: 15$, with the motion being recorded by a gravity barograph (Richard type) of the Observatory. Interestingly, the large earthquake of 1955Jan-31 (magnitude $6.2 \mathrm{mb}$ with epicenter $\sim 360$ $\mathrm{km}$ north of Cuiabá) had also been recorded by the barograph. The newspaper "O Dia", Curitiba, PR, 1957-Jan-20, transcribes a telegram from Cuiabá saying that "... a capital foi 'sacudida' por um tremor que não causou danos. A população ficou em estado de apreensão, a ponto de algumas pessoas telefonarem para os jornais questionando se o abalo seria proveniente da queda de um projétil teleguiado" ["the capital was 'shaken' by an earthquake that caused no damage. The population was in a state of apprehension, to the point that some people called the newspapers asking if the shock was due to the fall of a guided projectile"] . Given that the event was widely felt in the town, an intensity IV is probably appropriate.

It is unlikely that this event is an aftershock of the big 1955 earthquake. An initial search at the seismograms of LPB station (La Paz, Bolivia) did not show any signal that could be associated with this 1957 earthquake. 
1959 February 05 - 10:50 - Porto dos Gaúchos, MT

The original Catalog (Berrocal et al., 1984) did not list this event, which was added later to the BSB by UnB. A colony was founded in the northwest of Mato Grosso, called "Gleba Arinos", in May 1955, which was the origin of the town of Porto dos Gaúchos. A report from the colonizing company (Conomali, 1959) says that: "Dia 5 de fevereiro passou aqui pela gleba uma onda sísmica, que abalou tôdas as casas. Aqui na cantina as vigas rangiam, cairam objetos etc. O movimento foi precedido, acompanhado e seguido de "trovão", digo um ruido contínuo semelhante a trovão. Tivemos a impressão que a onda se afastava para norte ou um pouco para nordeste. ... Afirmam alguns que no mesmo dia sentiram por duas vezes o abalo. Quando no dia 5, às 10,50 ha da manhã, houve o terremoto, um dos rapazes do Sr. Francisco Wilke, esteve casualmente no fundo do pôço e correu perigo de ser sufocado pela terra que caiu, ao menos o susto foi grande." ["On February 5, a seismic wave passed through the land, which shook all the houses. Here in the canteen the beams creaked, objects fell, etc. The movement was preceded, accompanied and followed by "thunder", I mean a continuous thunder-like noise. We had the impression that the wave was moving towards the north or a little to northeast. ... Some say that on the same day they felt the shock twice. On the 5th, at 10.50 in the morning, when the earthquake happened, one of $\mathrm{Mr}$. Francisco Wilke's boys happened to be at the bottom of the well and was in danger of being suffocated by the earth that fell, at least it was quite frightening"]. An intensity $V$ is estimated based on the fall of objects.
It is possible that this 1959 event was a late aftershock of the large $m b 6.2$ earthquake of 1955 with epicenter $110 \mathrm{~km}$ south of Porto dos Gauchos. In this case an intensity $V$ at $110 \mathrm{~km}$ would give a magnitude of $m b \sim 4.8$ or higher, using the equation for felt area IV given in section 2. Alternatively, the epicenter could also be in the Porto dos Gauchos Seismic Zone, 73 $\mathrm{km}$ to the East (Barros et al., 2009), in which case it would have a magnitude $\mathrm{mb} \sim 4.5$ estimated by Barros (2010). However, there is not enough data yet for a definite conclusion on the 1959 epicenter and magnitude.

\section{November 04 - 18hs - Inhumas, GO}

A reporter for the "Diário do Paraná", Curitiba 1961-Nov-10, describes his visit to the village of Serra Abaixo, $\sim 13 \mathrm{~km}$ west of Inhumas, GO, where an earth tremor alarmed "hundreds" of people. The descriptions include houses shaking, rattling of dishes in the cupboards and pans in the kitchen. Fruit (mangos and guavas) fell from a tree. It lasted for 30 s to 1 minute. It was felt by all population with no exception. An intensity of $\mathrm{V}$ is tentatively estimated, giving a magnitude of about 3.5 .

\section{August 29 - 23hs - Corumbá, MS}

A tremor was felt in Cuiabá (MT) and Coxim (MS) around 23 hours, lasting $5 \mathrm{~s}$ ("Correio do Estado", Campo Grande, MS, 1963-Sept-03). It was also felt in Corumbá (MS) according to news from "A Tribuna", Corumbá, MS, transcribed by "Correio do Estado" in 1964Feb-19. It was not felt in Campo Grande. 
This event was recorded by LPB station ( $\mathrm{La}$ Paz, Bolivia). Figure 3 shows that the records are identical to those of the large mb 5.4 earthquake of 1964-Feb-13, which implies that the 1963 event was a precursor of the 1964 and so must have the same epicenter. The amplitude ratio between the two records $(1: 6)$ indicates that the 1963 precursor had a magnitude 0.8 units lower than the mainshock of 1964 , which gives an mb 4.6 for the 1963 event.

Corumbá, Coxim and Cuiabá are $145 \mathrm{~km}$, $210 \mathrm{~km}$ and $280 \mathrm{~km}$, respectively, from the epicenter (Fig. 4a). A felt area with about 200 $\mathrm{km}$ radius (as shown in Fig. 4a) indicates a magnitude $\mathrm{mb} 4.8$, quite consistent with the instrumental value of 4.6 .

\section{February 13 - 08:21:46 - Corumbá, MS}

The original Catalog of Berrocal et al. (1984) had no macroseismic information about this event. Some information on the depth, $5 \mathrm{~km}$ (Assumpção \& Suárez, 1988), and felt area was added later by USP and UnB to the Brazilian Seismic Bulletin (Assumpção et al., 1984). This event was felt in Campo Grande as a "slight tremor" by some people at the offices of "Correio do Estado". At avenue Calógeras 1050, eight people left the building; at another building people felt dizzy while noticing the tremor ("Correio do Estado", MS 1964-Feb-14). One person interviewed in 1984 by UnB described hanging lamps oscillating, which caused people to leave the building, but there was no noise of objects rattling (Assumpção et al., 1984) There is no evidence that the event was widely noticed in the city, so that an intensity III MM seems probable. In Corumbá it was felt as a slight tremor, with short duration, "1 sec at most", without any damage but alarming the population ("ligeiro tremor,... pequena duração, um segundo, se muito, não causou danos materiais, mas pregou um tremendo susto à nossa população" ["slight tremor, ... short duration, one second, if at all, did not cause material damage, but gave a tremendous scare to our population"]; source: "A Tribuna", Corumbá, transcribed by "Correio do Estado", Campo Grande, MS, 1964-Feb19). One person in Corumbá, interviewed in 1984 by UnB, said the "tremor lasted $3 \mathrm{~s}$, was felt by some people; there was noise of windows, doors and furniture, pictures oscillated and tables were displaced; one vase fell down" (Assumpção et al., 1984). Despite some inconsistencies in these reports, an intensity of IV for Corumbá seems appropriate.

The event was also felt in Pôrto Esperança at the margin of Paraguay river ("Correio do Estado", MS. 1964-Feb-17) without additional information to assign an intensity. We also received information that the 1964 event was felt in Fazenda Recreio in the Pantanal near the São Lourenço river, MS/MT border, (Teodoro Isnard, personal communication) without further details.

Interestingly, there is no news of this event being felt in Cuiabá (MT) or Coxim (MS) despite having a larger magnitude compared to its foreshock of August 1963. In Cuiabá newspapers were found yet that mentioned the tremor. Figure $4 b$ shows the localities where the event was felt: a tentative estimate of the felt area gives $A f=175 \times 10^{3} \mathrm{~km}^{2}$, corresponding to a magnitude of 4.9 , somewhat lower than the instrumental value of $\mathrm{mb} 5.4$. 


\section{$3 \mathrm{~min}$}

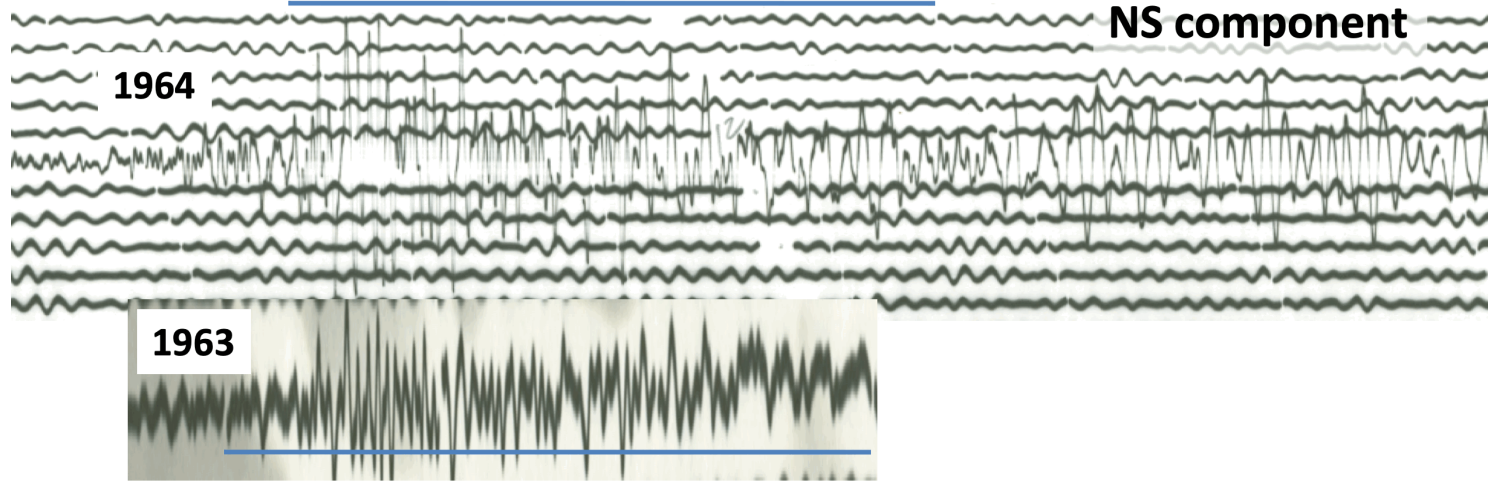

Figure 3 - Comparison of the records of the 1964-Feb-13 (above) and the 1963-Aug-29 (below) at LPB station (La Paz, Bolivia). N-S component. The time scale is the same; the vertical scale of the 1963 record is amplified $\sim 4$ times with respect to the 1964 trace. The 1963 event had amplitudes about 6 times lower, indicating a magnitude 0.8 units lower than the 1964 mainshock.
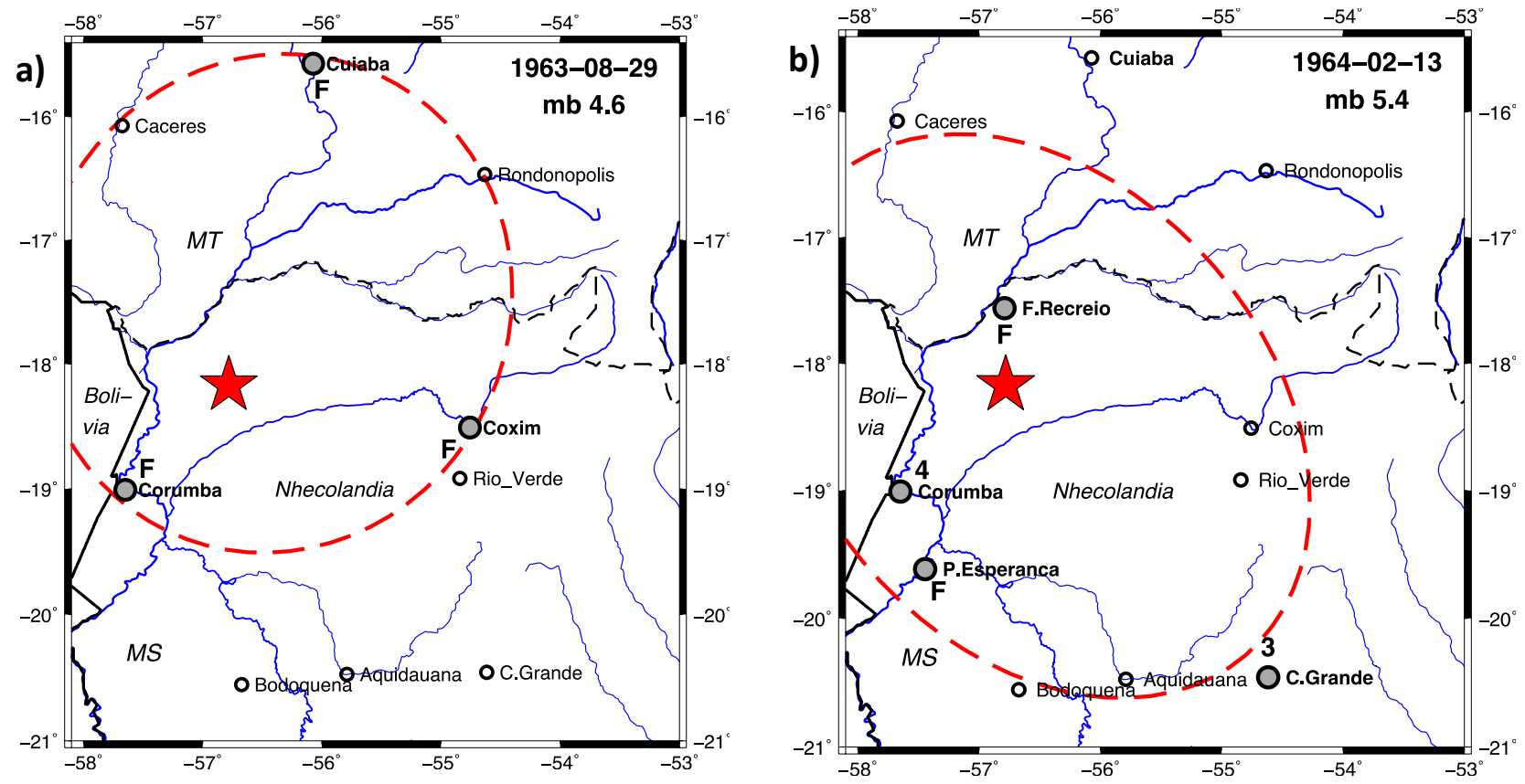

Figure 4. Locations of Corumbá, Cuiabá, Coxim and Campo Grande in relation to the ISC instrumental epicenter (red star) and tentative felt areas (dashed red line). Thick solid line is Brazil border; dashed line is MT/MS state boundary; blue lines are rivers. Open circles are locations with no information about the event being felt; gray circles are places where the event was felt. Arabic numbers are MM intensities; "F" means the event was felt but there is not enough information to assign an intensity. a) 1963-Aug-29 mb 4.6. b) mainshock of 1964-Feb-13 mb 5.4. Symbols as in Figure 2. 
1968 October 08 - 00:26 - Nhecolândia, MS

The "Correio do Estado", Campo Grande, MS, 1968-Oct-09, reports an earth tremor felt in Coxim and Rio Verde, for "30 seconds", alarming the two populations. In Coxim, the exmayor said to the newspaper that "it lasted a few seconds" and even "alarmed several people of the town" ("chegando assustar várias pessoas da cidade"). In Rio Verde one witness said "the woodframe of several houses made noise" ("rangeu o madeiramento de diversas casas").

The edition of "Correio do Estado", 1968-Oct15, transcribes news from the newspaper "Fôlha da Tarde", Corumbá, saying that people from the northern part of Nhecolândia, near Rio Verde, were awakened by a noise similar to the passage of a jet-plane, and then felt the earth tremor, shaking doors and furniture. The newspaper says that "information from Sagrado and Divino farms confirmed the event".

The descriptions above suggest an intensity IV MM at Rio Verde and the northern part of Nhecolândia. In Coxim, there is not enough information to assign an intensity, so a classification of III or IV is tentatively assigned. It is not clear if the description of "shaking doors and furniture", mentioned above, applies to the Divino and Sagrado farms as well. Assuming an epicenter in the middle of the felt area, Figure 5 shows the event could have been felt in an approximate radius of $\sim 50$ to $100 \mathrm{~km}$, which gives a magnitude about 3.8 to 4.2. A preliminary magnitude of 4.0 is adopted for this event. Interestingly, this event does not seem to have been recorded by the array station of Brasilia, which started operating in 1967-1968 (Berrocal, 1974).

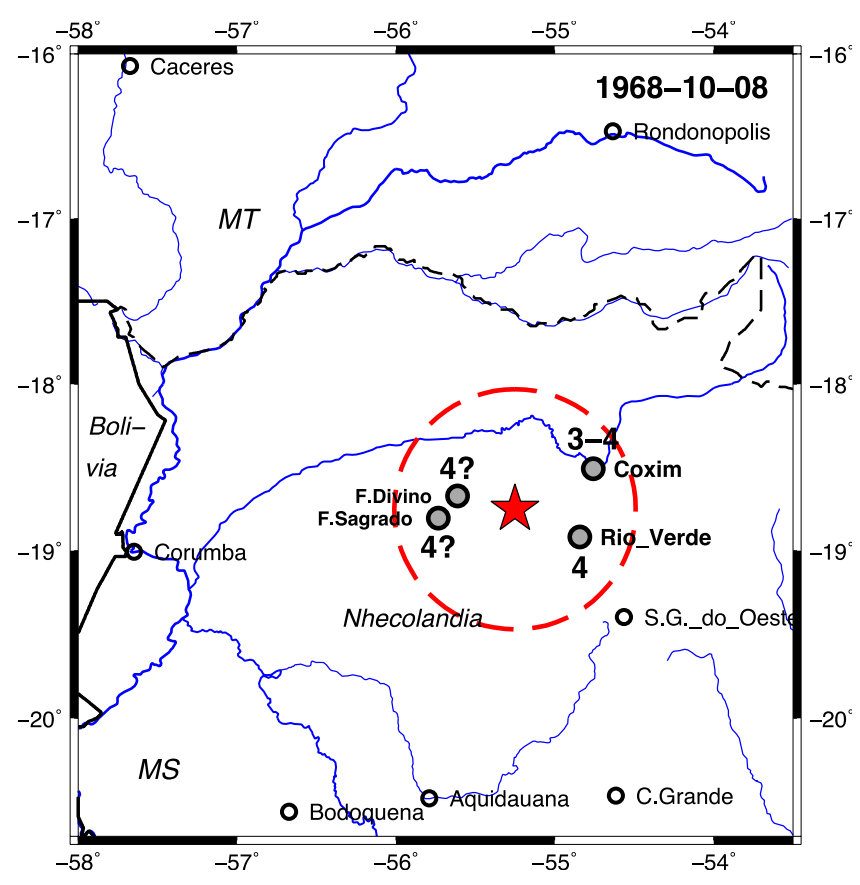

Figure 5 - Felt area of the 1968-Oct-08 event. Symbols as in Figure 4.

\section{REVISED SEISMICITY OF THE WEST-CENTRAL BRAZIL AND SEISMOTECTONICS}

The new information described above are summarized in Table 1. Figure 6 shows all the new events (red and blue symbols) compared to the previous data in the original Catalog (black symbols), up to 1981 . The new information is a significant contribution to the historical earthquake catalog of West-Central Brazil and was used to update the catalog of Brazilian earthquakes. Besides information on the seismic events, other events, such as news from meteorite falls (commonly reporting "tremors") and false events (such as wrong dates of old events reported by newspapers) were also included in the updated Brazilian catalog.

Figure 7 shows the seismicity of this updated catalog up to 2019. Due to its deep and transcontinental scale (Cordani et al., 2013), 


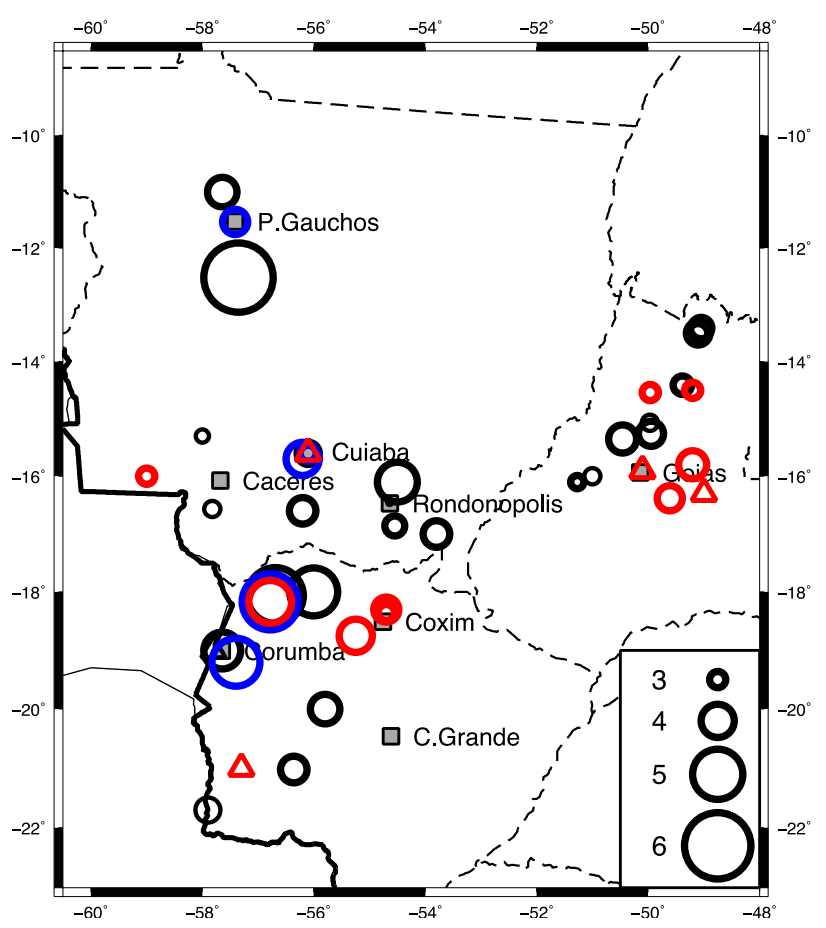

Figure 6 - Comparison of the epicenters of the Brazilian Seismic Bulletin (black circles and triangles) until 1981, and the data from this paper (colored symbols). Blue circles are new contributing information about existing events (class "c" in Table 1). New seismic events ("ns" in Table 1) are indicated by red circles when magnitudes were estimated by felt area or maximum intensity (magnitude type "3" or "4" in Table 1, respectively), and triangles when there is no information (magnitude type "-1" and category "C", Table 1).

some suggestions had been made in the past that the Transbrasiliano Lineament (LTB) could be interpreted as a weak zone responsible for the seismicity in Central Brazil and the Pantanal region, especially based on an old interpretation of the LTB trace crossing the Pantanal. Figure 7 shows that the earthquakes occur west of the LTB in the Pantanal basin, and East of the LTB in Goiás and Tocantins. This does not favor a link between seismicity and the LTB, as suggested earlier by Assumpção et al. (1986). In addition, despite the fact that sedimentary basins hide many basement structures and faults, Figure 7 does not suggest any visual correlation between epicentral clusters and density of mapped faults.
Figure 8a compares the seismicity with upper mantle P-wave anomalies at $200 \mathrm{~km}$ depth based on the tomography results of Rocha et al. (2019). Low velocities at lithospheric depths are usually interpreted as indirect indication of lithospheric thinning, with a shallower high temperature asthenosphere. This feature has been used to explain the seismicity in SE and Central Brazil (Assumpção et al., 2004; Rocha et al., 2016) whereby the hotter lithospheric mantle, just beneath the crust, is not strong enough to support high levels of the regional stress field, which then accumulate in the upper crust (Assumpção et al., 2004).

Alternatively, seismicity also correlates with gravity free-air anomalies (Fig. 8b). Positive freeair anomalies usually indicate higher density bodies in the crust, which are not totally compensated isostatically. For example, positive gravity anomalies can be caused by large areas of high topography not totally compensated by a thicker crust, or areas of very thin crust not compensated by thick sedimentary basins. In either case, the high density loads in the lithosphere can cause flexural deformation of the lithospheric plate resulting in compressional stresses in the upper crust, as modelled by Assumpção \& Sacek (2013) in Central Brazil. Assumpção et al. (2014) had shown this correlation for other areas in Brazil.

Explaining intraplate seismicity is a huge challenge for seismologists and many different models have been proposed (e.g., Mazzotti, 2007; Talwani, 2014). Few earthquakes had their focal depth well determined. For the Pantanal basin, well determined depths were possible for the $5.4 \mathrm{mb} 1964$ event $(5 \mathrm{~km}$, Assumpção \& Suárez, 1988), and the $4.8 \mathrm{mb}$ Coxim event of 2009 (6 km, Dias et al., 2016). In Goiás, only one 
raw catalog (1720-2019)

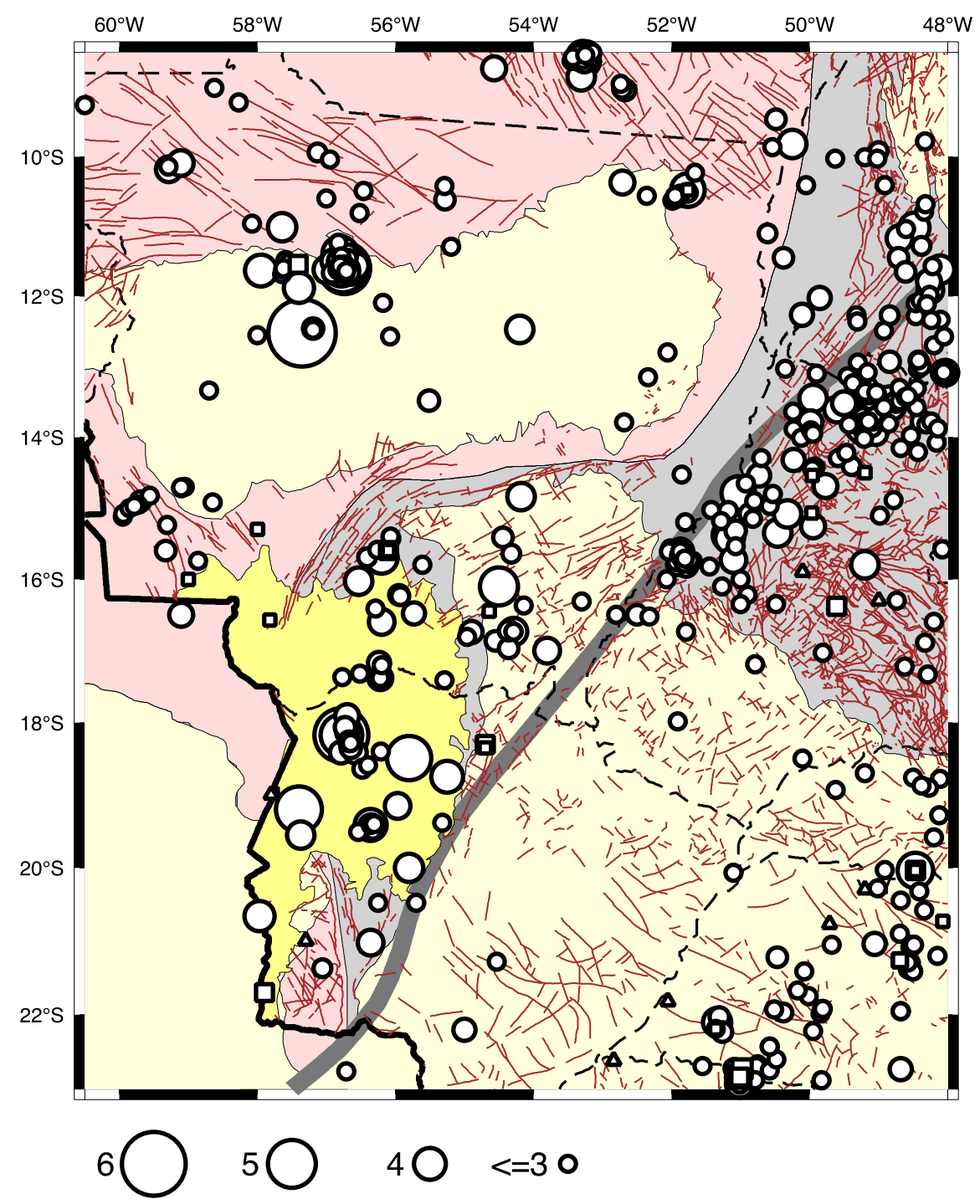

Figure 7 - Seismotectonic map of the West-Central region of Brazil. Background color as in Figure 1; brown lines are faults from CPRM database. Events from the revised updated catalog. Circles are epicenters of events with magnitudes calculated by instruments or felt area; small squares are events with magnitudes estimated form the felt intensity in a single location (assumed to be the maximum epicentral intensity); small triangles are events with no magnitude or intensity information. The gray line is the Transbrasiliano Lineament (Cordani et al., 2016).

earthquake (2010 Mara Rosa event with $5.0 \mathrm{mb}$ ) had a well constrained depth of $1.4 \mathrm{~km}$ (Barros et al., 2015). Although earthquake activity is concentrated in the upper crust, the main causes may be located deep in the lithosphere unrelated to shallow features mapped at the surface.

\section{FREQUENCY-MAGNITUDE RELATION FOR THE PANTANAL REGION}

A preliminary estimate of the frequencymagnitude relation for earthquakes in the Pantanal is now presented. Defining seismic zones in intraplate settings is a challenging task. 

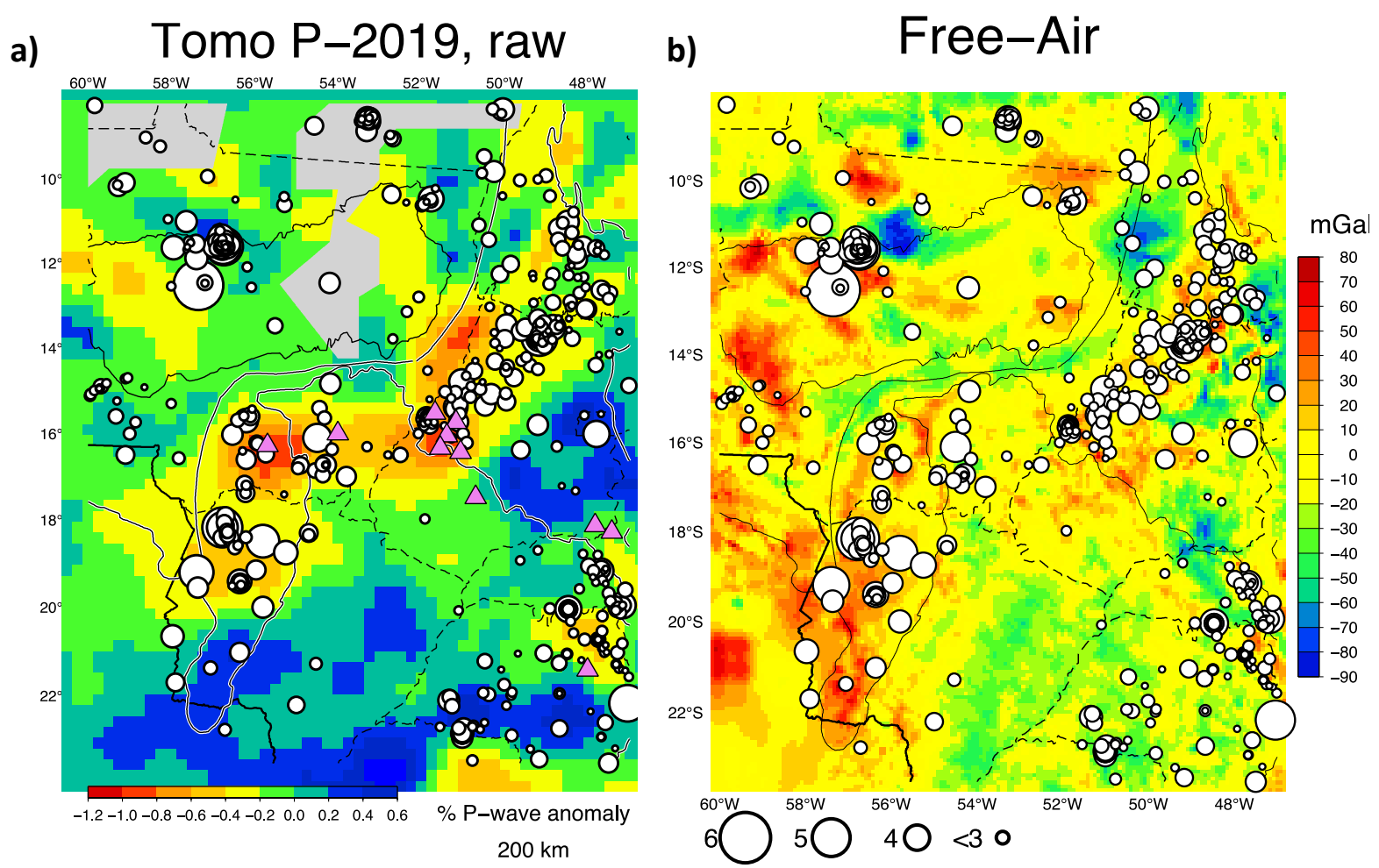

Figure 8 - a) P-wave velocity anomaly at $200 \mathrm{~km}$ depth from teleseismic tomography (Rocha et al., 2019). Low velocities are interpreted as a thin lithosphere (shallower asthenosphere). Gray patches are areas with little resolution in the tomography. Violet triangles are Upper Mesozoic (80 to $60 \mathrm{Ma}$ ) pipes denoting intraplate magmatism, probably facilitated by a thin lithosphere. b) Free-air gravity anomaly (Sá, 2004). Positive anomalies indicate lithospheric high-density loads, not totally compensated, which causes downwards flexural deformation and compressive stresses in the upper crust. Note that the epicenters (revised raw catalog, $1744-2019, \mathrm{mb} \geq 2.5$ ) are mostly in areas of positive gravity anomalies..

However, based on the concentration of epicenters, the general low P-wave velocities (presumably thin lithosphere) and positive gravity anomalies (Fig. 8), a polygonal zone was defined including the whole Pantanal basin and a small area to the South and to the NE, as seen in Figure 9a.

To calculate the Gutenberg-Richter frequency-magnitude relation, the magnitude completeness thresholds needs to be determined. Based on the historical record and evolution of the seismographic stations in Brazil, we estimated the completeness levels shown in Table 2. This threshold level is represented by the blue line in the magnitude-time plot of Figure 9a. We assume that any other event with similar magnitude to the 1906 earthquake (felt up to about $200 \mathrm{~km}$ away) would have been reported in newspapers. So, we estimate that magnitudes larger than 4.8 should be complete in our catalog since about 1900 . Due to the sparse population of the Pantanal, smaller magnitudes could only be detected by seismographic stations. Table 2 shows the decrease of the detectability as the number of stations in Brazil increased. With the larger number of stations installed in Mato Grosso and Mato Grosso do Sul states in the last few years, any event with magnitude mR 3.0 or 

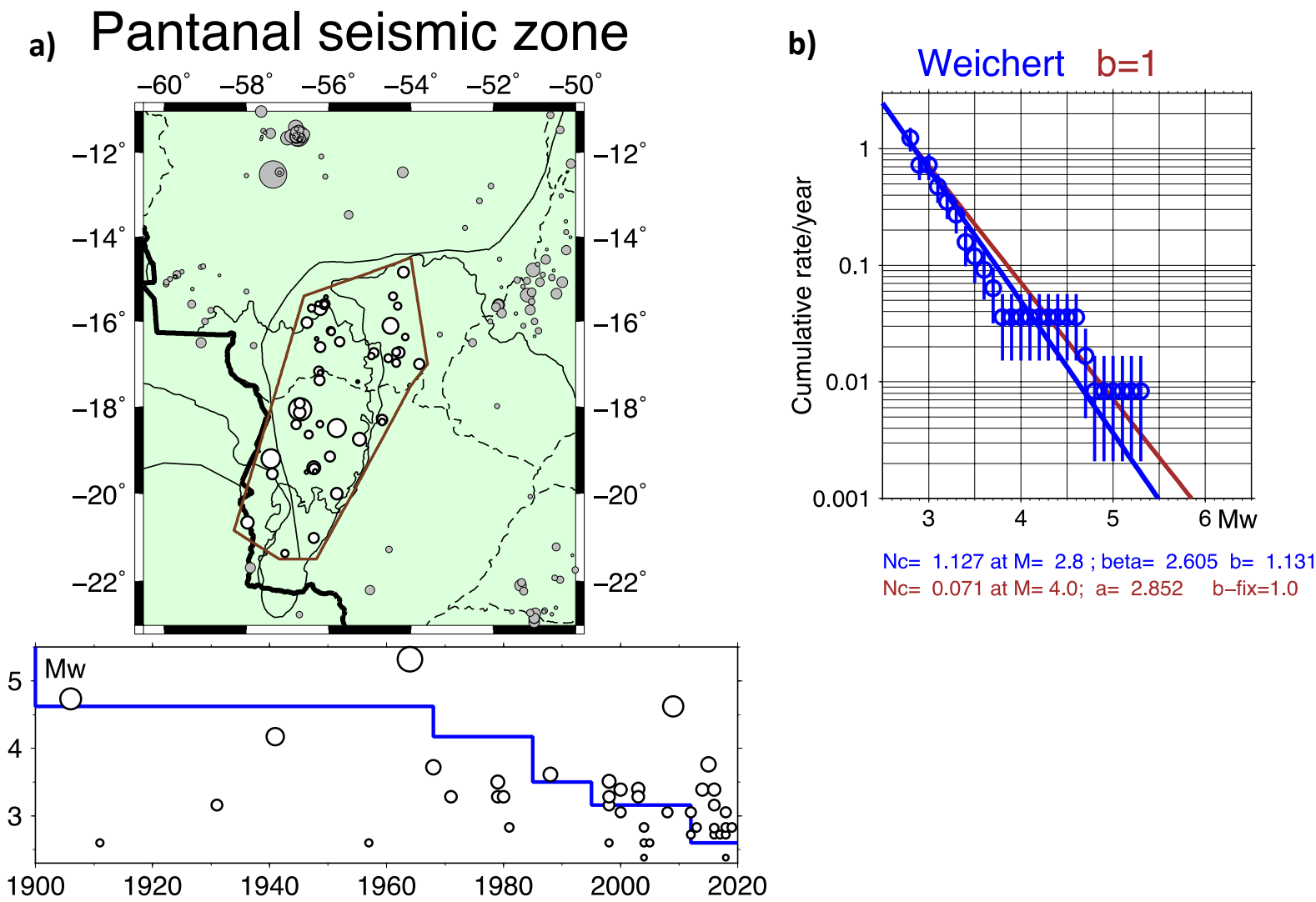

Figure 9 - a, top) Epicenters of the Pantanal "seismic zone". Declustered catalog: open circles are the events selected inside the seismic zone. a, bottom) Magnitude $x$ time evolution. The blue line is the magnitude threshold limit (completeness level) used to estimate de magnitude frequency distribution. b) Gutenberg-Richter cumulative frequency-magnitude relation: blue line is the fit with the Weichert (1980) method, brown line has a fixed b-value = 1.0 , for comparison. Nc is the cumulative number of annual events with magnitude above $\mathrm{M}$.

above can be detected and located. Table 1 shows the corresponding converted Mw magnitude using the formula (Drouet \& Assumpção, 2015).

$$
M w=1.121-0.76 m R
$$

To estimate the frequency-magnitude relation, the catalog must be declustered. That is, all small foreshocks and aftershocks must be treated to produce a catalog of independent events to be used in statistics and seismic hazard analysis. We used the Reasenberg (1985) method combining the energies of the foreshocks and aftershocks with that of the main event producing a slightly larger equivalent magnitude. This better represents the impact of the main event when we have long sequences of earthquakes with the largest magnitude not much higher than the second largest. Besides the 1963/1964 events mentioned earlier, six other cluster were identified in the Pantanal seismic zone of Figure 9a.

Figure $9 \mathrm{~b}$ shows the annual number of events, per magnitude, using the earthquakes above the threshold line (blue line in Fig. 9a). Using the maximum likelihood method for varying completeness periods (Weichert, 1980), we get a $b$-value $=1.13 \pm 0.18$ (blue line in Fig. 9b). 


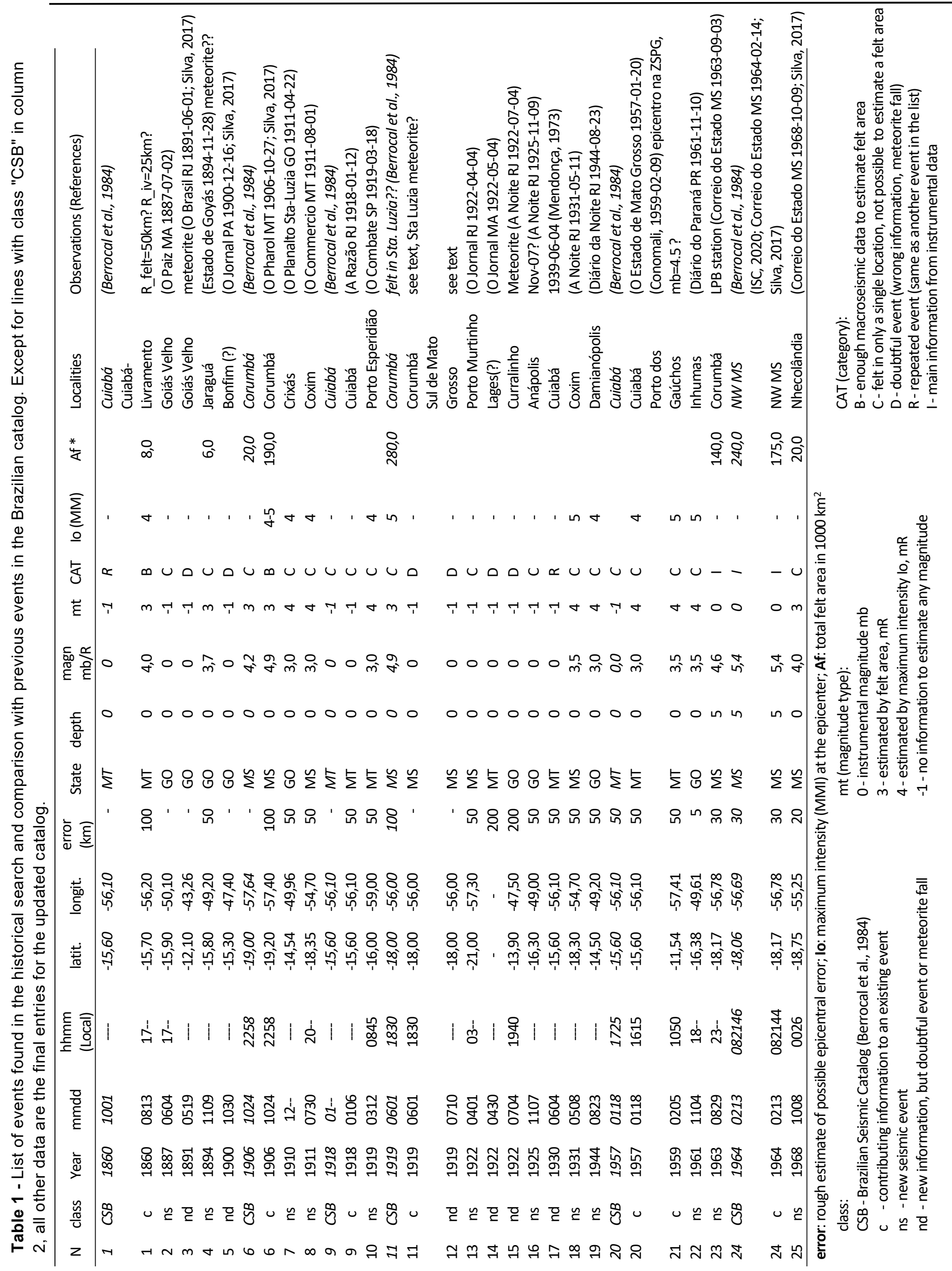


Table 2 - Magnitude completeness threshold estimated for the Pantanal region.

\begin{tabular}{|c|c|c|c|}
\hline$m b / m R$ & $M w$ & $\begin{array}{l}\text { year } \\
\text { range }\end{array}$ & Observation \\
\hline 4.8 & 4.62 & $\begin{array}{l}1900- \\
2019\end{array}$ & $\begin{array}{l}\text { Felt in a radius of } \sim 200- \\
300 \mathrm{~km} \text {. Should be } \\
\text { reported in newspapers }\end{array}$ \\
\hline 4.4 & 4.17 & $\begin{array}{l}1968- \\
2019\end{array}$ & $\begin{array}{l}\text { Beginning of Brasilia array } \\
\text { station }\end{array}$ \\
\hline 3.8 & 3.50 & $\begin{array}{l}1985- \\
2019\end{array}$ & $\begin{array}{l}\text { Increase of stations in SE } \\
\text { and Central Brazil }\end{array}$ \\
\hline 3.5 & 3.16 & $\begin{array}{l}1995- \\
2019\end{array}$ & $\begin{array}{l}\text { Further increase of } \\
\text { stations in SE and Central } \\
\text { Brazil }\end{array}$ \\
\hline 3.0 & 2.60 & $\begin{array}{l}2012- \\
2019\end{array}$ & $\begin{array}{l}\text { Increase of stations near } \\
\text { the Pantanal region }\end{array}$ \\
\hline
\end{tabular}

Given the uncertainty in the $b$-value, a preferred relation with a fixed $b$-value $=1.0$ (brown line in Fig. 9b) can be drawn as:

$$
\begin{aligned}
\log (N c)=a & -b m \\
& =2.85-1.0 \mathrm{Mw}
\end{aligned}
$$

which gives a magnitude $M w \geq 4.0$ every 14 years, and an $M w \geq 5$ every 140 years.

\section{CONCLUSION}

A detailed search for historical records of past earthquakes in Central-West Brazil was carried out in newspapers archives. One large earthquake in 1919, listed in the previous Brazilian catalog with magnitude $4.9 \mathrm{mb}$, was found not to be correct and was discarded. On the other hand, an event in 1906 was found to have been felt over a larger area and its magnitude was increased from mb 4.2 to 4.9. This revision affects the earthquake rate of large magnitudes and the estimated $b$-value. Several small new events were found. The revised catalog confirmed the trend of high seismicity inside the Pantanal basin and along the Goiás-Tocantins seismic zone. The causes of the seismicity in the Pantanal and the Goiás-Tocantins seismic zones are probably related to deep crustal and lithospheric features causing stress concentrations in the upper crust, and may have little relationship with the Transbrasiliano Lineament.

\section{ACKNOWLEDGMENTS}

The authors thank Biblioteca Nacional for their excellent digital newspaper database, and "Correio do Estado", Campo Grande, for access to their digitized collection. M.A. thanks FAPESP (project 2013/24215-6) and CNPq (30.1284/2017-2) for support. L.J.S. and E.M.F. thank UFMS and FUNDECT/CAPES (Universal project 20/2010).

\section{REFERENCES}

ASSUMPÇÃO M. 1983. A regional magnitude scale for Brazil. Bull. Seism. Soc. Am., 73: 237-246.

ASSUMPÇÃO M \& BURTON P. 1985. Atenuação de intensidades macrossísmicas no Brasil e estimativa de risco sísmico no Sudeste. In: $1^{\circ}$ Encontro Regional da Soc. Bras. de Geofísica. São José dos Campos, SP, Brazil: SBGf.

ASSUMPÇÃO M \& SACEK V. 2013. Intraplate seismicity and flexural stresses in Central Brazil. Geophys. Res. Lett., 40: 487-491. doi: 10.1002/grl.50142 
ASSUMPÇÃO M \& SUÁREZ G. 1988. Source mechanisms of moderate size earthquakes and stress orientation in mid-plate South America. Geophys. J., 92: 253-267.

ASSUMPÇÃO M, ROSA JWC, VELOSO JA, FERNANDES EP \& BERROCAL J. 1984. Contribuição ao estudo da sismicidade do CentroOeste. In: 33․ Congr. Bras. Geologia. Rio de Janeiro, RJ, Brazil: SBG. p. 2051-2057.

ASSUMPÇÃO M, LIMA TM \& TOMÁS LAR. 1986. O sismo de Araguapaz de 14.01 .86 e o Lineamento Transbrasiliano. In: XXXIV Congr. Bras. Geol. Goiânia, GO, Brazil: SBG. 6: 2573-2580.

ASSUMPÇÃO M, SCHIMMEL M, ESCALANTE C, ROCHA M, BARBOSA JR \& BARROS LV. 2004. Intraplate seismicity in SE Brazil: Stress concentration in lithospheric thin spots. Geophysical J. Int., 159: 390-399. doi: 10.1111/j.1365-246X.2004.02357.x

ASSUMPÇÃO M, FERREIRA J, BARROS L, BEZERRA FH, FRANÇA GS, BARBOSA JR, MENEZES E, RIBOTTA LC, PIRCHINER M, NASCIMENTO A \& DOURADO JC. 2014. Intraplate Seismicity in Brazil. In: TALWANI P (Ed.). Intraplate Earthquakes. Cambridge University Press, chapter 3, p. 50-71. ISBN 978-1-10704038-0.

BARROS LV. 2010. Sismicidade, Esforços Tectônicos e Estrutural Crustal da Zona Sísmica de Porto dos Gaúchos, MT. Doctorate Thesis, Universidade de Brasília, Inst. de Geociências, DF, Brazil. 176 pp.

BARROS LV, ASSUMPÇÃO M, QUINTERO R \& CAIXETA D. 2009. The intraplate Porto dos Gaúchos seismic zone in the Amazon craton Brazil. Tectonophysics, 469(1-4): 37-47. doi: 10.1016/j.tecto.2009.01.006

BARROS LV, ASSUMPÇÃO M, CHIMPLIGANOND C, CARVALHO JM, VON HUELSEN MG, CAIXETA
D, FRANÇA GS, ALBUQUERQUE DF, FERREIRA VM, \& FONTENELE DP. 2015. The Mara Rosa 2010 GT-5 earthquake and its possible relationship with the continental-scale Transbrasiliano Lineament. J. S. Am. Earth Sci., 60: 1-9. doi: 10.1016/j.jsames.2015.02.002

BERROCAL J. 1974. South American seismotectonics from SAAS data. Ph.D. thesis, Edinburgh University, Scotland. 240 pp.

BERROCAL J, ASSUMPÇÃO M, ANTEZANA R, DIAS NETO CM, ORTEGA R, FRANÇA $H$ \& VELOSO J. 1984. Sismicidade do Brasil. São Paulo, SP, Brazil. IAG-USP/CNEN. 320 pp.

BIANCHI MB, ASSUMPÇÃO M, ROCHA MP, CARVALHO JM, AZEVEDO PA, FONTES SL, DIAS FL, FERREIRA JM, NASCIMENTO AF, FERREIRA MV \& COSTA ISL. 2018. The Brazilian Seismographic Network (RSBR): Improving seismic monitoring in Brazil. Seism. Res. Lett., 89(2A): 452-457. doi: 10.1785/0220170227

BRANNER JC. 1912. Earthquakes in Brazil. Bull. Seism. Soc. Am., 2(2): 105-117.

BRANNER JC. 1920. Recent earthquakes in Brazil. Bull. Seism. Soc. Am., 10(2): 90-104.

CONOMALI. 1959. Colonia Colonizadora Noroeste Matogrossense (Conomali), Relatório no. 54, 09-Feb-1959. Available on: <https://www.conomali.com.br>. Cronologia/1959. Access on: July 20, 2020. Also personal records of Mr. Henrique Meyer.

CORDANI UG, PIMENTEL MM, DE ARAÚJO CEG \& FUCK RA. 2013. The significance of the Transbrasiliano-Kandi tectonic corridor for the amalgamation of West Gondwana. Brazilian Journal of Geology, 43(3): 583-597.

DIAS FL, ASSUMPÇÃO M, FACINCANI EM, FRANÇA GS, ASSINE ML, PARANHOS FILHO AC \& GAMARRA RM. 2016. The 2009 earthquake, 
magnitude $\mathrm{m}_{\mathrm{b}} 4.8$, in the Pantanal Wetlands, West-Central Brazil. Annals Braz. Acad. Sci., 88(3): 1253-1264. doi: 10.1590/00013765201620140507

DROUET S \& ASSUMPÇÃO M. 2015. Source, attenuation and site parameters from spectral analysis of Brazilian earthquakes. In: XV SNET XV Simpósio Nacional de Estudos Tectônicos / IX International Symposium on Tectonics. Vitória, ES, Brazil: Braz. Geology Soc. Extended Abstract.

ISC. 2020. ISC Bulletin. International Seismological Centre, UK. On-line Bulletin. doi: 10.31905/D808B830

LEMOS A. 1921. Boletim Sismológico do Observatório Nacional, 1906-1920. Observatório Nacional, Rio de Janeiro, RJ, Brazil: Imprensa Nacional. 73 pp.

MAZZOTTI S. 2007. Geodynamic models for earthquake studies in intraplate North America. In: STEIN S \& MAZZOTTI S (Eds.). Continental Intraplate Earthquakes: Science, Hazard, and Policy Issues. Colorado, USA. The Geological Society of America, Special Paper 425, p. 17-33.

MENDONÇA E. 1973. Datas Matogrossenses. 2nd ed., Ed. Casa Civil do Governo do Estado de Mato Grosso, Cuiabá, MS, Brazil.

REASENBERG P. 1985. Second-order moment of Central California seismicity, 1969-1982. J. Geophys. Res., 90(B7): 5479-5495.
ROCHA MP, AZEVEDO PA, MAROTTA GS, SCHIMMEL M \& FUCK R. 2016. Causes of intraplate seismicity in central Brazil from travel time seismic tomography. Tectonophysics, 680: 1-7.

ROCHA MP, ASSUMPÇÃO M, AFFONSO GMPC, AZEVEDO PA \& BIANCHI M. 2019. Teleseismic $P$ wave Tomography Beneath the Pantanal, Paraná, and Chaco-Paraná Basins, SE South America: Delimiting Lithospheric Blocks of the SW Gondwana Assemblage. J. Geophys. Res. - Solid Earth, 124: 7120-7137. doi: 10.1029/2018jb016807.

SÁ NC. 2004. O campo de gravidade, o geóide e a estrutura crustal na América do Sul: Novas estratégias de representação. Tese de LivreDocência, Universidade de São Paulo, SP, Brazil. $121 \mathrm{pp}$.

SILVA LJ. 2017. Levantamento histórico, cartográfico e análise da atividade sísmica na região Centro-Oeste do Brasil: ênfase na Bacia Sedimentar do Pantanal. M.Sc. Dissertation, Universidade Federal de Mato Grosso do Sul, Aquidauana, MS, Brazil. 154 pp.

TALWANI P. 2014. Unified model for intraplate earthquakes. In: TALWANI P (Ed.). Intraplate Earthquakes. Cambridge University Press, chapter 11, p. 275-302. ISBN 978-1-107-04038-0.

WEICHERT DH. 1980. Estimation of the earthquake recurrence parameters for unequal observation periods for different magnitudes. Bull. Seismol. Soc. Am., 70(4): 1337-1346 